\title{
Universities and Public Administrations' Institutions in Albania: The Cooperation between Them from the Point of Views of Students
}

\author{
Teuta Nunaj, PhD. (c) \\ Department of Business, Management and Tourism, \\ Non-Public Institution of Higher Education "University Marin Barleti", Albania \\ Email: teuta.nunaj@gmail.com
}

\section{Doi:10.5901/mjss.2016.v7n6p195}

\begin{abstract}
This study analyses two main topics: the first topic is related to the necessary factors that help the collaboration between universities and public administration institutions and the second topic is to examine the possible indicators that affect the student's motivation to study Public Administration in the public universities, in Albania. It is important to know the indicators that measure student's motivations regarding Public Administration and lead them to choose this branch of study and is also crucial to know what expectations they have for the curriculum of university. The research question is: Why the collaboration between universities and the institutions of public administration in Albania is a necessity? The results are based on: the empirical data obtained from two public universities in Albania which have Public Administration in their curricula; on five elite interviews; and on survey completed by162 students that study Master degree in Public Administration. By using qualitative and quantitative method it was found that Albanian students are motivated to study Public Administration at university but one student in three have difficulties in obtaining new knowledge from the curricula. It is found that universities and public administration's institutions have no a strong relationship between them. They should collaborate more with each other in order to provide more possibilities to students, to offer them a professional practicum in the public institutions and for common scientific studies as well.
\end{abstract}

Keywords: Student Motivation, Education of Public Administration, University Curricula.

\section{Introduction}

Albania has declared its independence 103 years ago, and the Albanian public administration was established in the same period by substituting the ottoman administration. In 1990, the new political system was associated with the change of the economic and social system. The study of Public Administration subject at the university level began in 1993. At first it was appeared in University of Tirana, which in that period of time was the biggest university in Albania. Public Administration is analyzed scientifically abroad for many years, but in Albania it was an inexistent field before ' 90 s and its value was unknown.

Public Administrations' students are assumed to be the future employees of the public civil service and for this reason this study is focused on the students that study Public Administration. Also the aim of this research paper is to analyze some factors, which are considered as important ones in the collaboration between universities and institutions of public administration in Albania. And it is necessary to add that through this research we want to study if this collaboration can have an impact in the motivation of students to study Public Administration or not.

The first part of the essay will explain same authors' points of view related to Public Administration concept. The second part will continue with empirical data analysis, collected from two public universities that have the subject of Public Administration in their curricula: University of Tirana (UT) and "Aleksandër Moisiu" University of Durrës (AMUD).

\section{Literature}

In the context of this essay, the Public Administration will be treated as a subject of Albanian academic study and not as an activity of the Albanian public institutions. Abroad, "the science of public administration was born toward the end of the nineteenth century when the business of the state started to attract social-academic attention. The revolution that turned public administration into an independent science and profession is traditionally related with the influential work and vision of Woodrow Wilson (1887) and Frank J. Goodnow (1900). These scholars were among the first who advocated the autonomy of the field as a unique area of science that drew substance from several sources" (Vigoda, 2002:2). 
At the beginning, the public administration was studied in a political science framework because the development of the public sector does not have any meaning without the development of politics in general. In his famous essay "The study of administration", Woodrow Wilson, former President of USA wrote: "No one wrote systematically of administration as a branch of the science of government until the present century [XIX]" (Wilson, 1887:198).

But the Public Administration was not developed only in the United States. According Daniel W. Martin, "Virtually every significant concept that existed in the American literature as late as 1937 had already been published in France by 1859; most had been published by 1812" (Martin, 1987:297). He argues in his essay "Déjà Vu: French Antecedents of American Public Administration" that public administration does not belong with the essay "The study of administration", but to the French public administration literature.

Ali Riza Sakli, in his essay "The German and Bluntschli Influence on the Establishment of Public Administration", argues another beginning of public administration. He writes: "The American political science and public administration had been profoundly influenced by German political theory by late 19th Century. Back then, thousands of students were flocking to Germany to go to university for a few semesters there." (2013:160).

The first studies of the public administration discipline in USA brought at the same time the beginning of these studies as a subject in the American universities. Meanwhile, "The University of Pennsylvania and Columbia University began to offer courses in public administration as early as 1888. The University of Chicago appointed the nation's first professor of public administration in 1899, and in 1900 Frank Goodnow of Columbia published perhaps the first public administration textbook" (Lynn, 1996:27). But, in Albania, until in now that we are writing this essay, we do not have any proper academic or university text for public administration published by Albanian authors. For nearly 25 years, our students have been studying with foreign text, written by foreign authors, translated in the Albanian language by foreign literature and creating by this way a big gap in Albanian public administration studies

Internationally, through the centuries, the way of studying public administration has changed a lot. Its field of activity and its analysis grew and expanded as it was combined with other fields. Before 1980s, in Great Britain, the public administration, as an object of the study, "was largely approached with a social science perspective. Its academic location, as one subject developed in British higher education, was usually in social science or related departments" (Greenwood, Eggins, 1995:143). After that, again in Great Britain "during the 1980s, the curriculum moved sharply away from the social science, towards business and management, with considerable implications both for the subject's development and approaches to its delivery in teaching institutions" (Greenwood, Eggins, 1995:143). This development "reflected the changing structure and operations of public bureaucracies - in both Britain and much of the Western world" (Greenwood, Pyper and Wilson, 2002:20).

This change was spread in different countries of the world and by Eran Vigoda, "today many examples exist in universities of independent public administration units; some operate as schools and some operate as freestanding faculties. In at least an equal number of universities, however, public administration programs on all levels are only part of larger units such as political science departments, business and management schools, or even public affairs schools" (Vigoda, 2002:5).

While in the world, the debates for public administration curricula and this field of study, treating the public administration in a context of a profession and practice are followed with more unresolved problems, in Albania these debates are absent. One important reason for this problem is the lack of depth research studies in this important field as Albanian is moving towards integration in EU. The Albanian universities should aim to not only give students knowledge for the branch they study, but should also help to boost their skills. In our case, the universities offer academic skills in auditoriums through different courses but they give minimal help to increase students' abilities because students complete a practice in public institutions for a very short period of time. The students of the Bachelor curricula complete a practice only once a month in their final year while some universities do not offer it at all. The students of the Master program complete a practice only once at the three months in the last year of study.

\section{Research Methodology}

The collaboration between Albanian universities and public administration' institutions, as well as the indicators that motivate students to study Public Administration will be in the focus of this research paper. The data are collected during 2013-2015 and this period of time corresponds with two academic years 2013-2014 and 2014-2015. Students in the sample were part of Master's program in this period. The data are obtained from March until June 2015. 5 elite interviews were conducted. The population includes all the students that study Public Administration at Master level at two Albanian

1 In 1893 Goodnow had published the two volumes Comparative Administrative Law, the first American treatise on public administration. 
public universities. The population was composed by 363 students: 197 students from UT and 166 students from AMUD. The sample was 157 students who were chosen randomly. The questionnaires were distributed in hard copies to 180 Master students and 162 were turned back, or $90 \%$ of the total number: specifically 91 questionnaires from UT and 71 questionnaires from AMUD. The sample of 162 Master students gives us the confidence level of $94 \%$ with a margin error $6 \%$. The data of questionnaires were processed using SPSS Statistics.

The questionnaire contains totally 11 questions, 5 questions collect general data about the participants and 6 questions collect data for the issue that are addressed in the study. The questionnaire have 5 closed questions and 6 semi-closed questions. In one question the students had the possibility to prioritize three alternatives, first choice, second choice, and third choice from a group of alternatives. "Other" was another alternative in the same question and gives the participants the possibility to choose other options.

\subsection{Auxiliary research question:}

- Are Albanian students motivated to study Public Administration at university?

- What kind of the motivation they have, do they have intrinsic or extrinsic motivation?

- Which are the students' expectation for their curriculum at university?

- Which is the level of the collaboration between universities and public administration' institutions in Albania?

\subsection{Objectives of the research:}

- To measure the motivation of students to study Public Administration at university.

- To analyze the expectations of students for their curricula at university.

- To analyze the collaboration between universities and public administration' institutions.

\section{Data analysis and results}

This part of the study will continue with the elaboration of empirical data in SPSS Statistics and will answer the research questions. Figure 1. Provides data related with respondents gender and in Figure 2 is shown the percentage of each group based on their age:

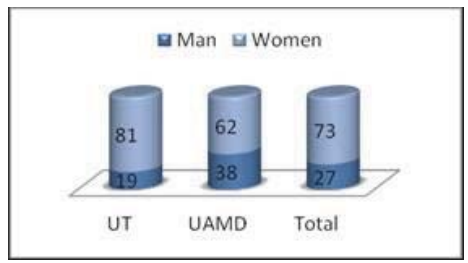

Figure 1: Surveyors by gender (\%)

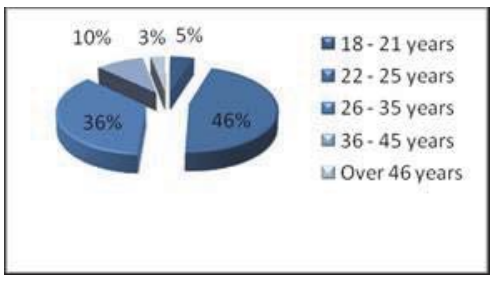

Figure 2: Surveyors by age (\%)

A total number of 162 Public Administration Master Students participated in this study which specifically included 118 students (73\% of those samples) in first-year and 44 students (27\%) in second-year; 110 students (62\%) study Master of Science, 22 students (14\%) study Professional Master and 39 students (24\%) study Master Part Time. 
The status of students as employed or unemployed is illustrated in Figure 3 and 4:

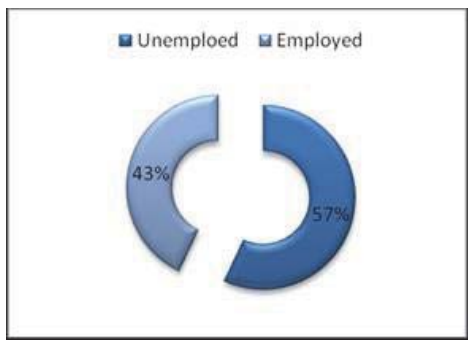

Figure 3: Surveyors by status of work (\%)

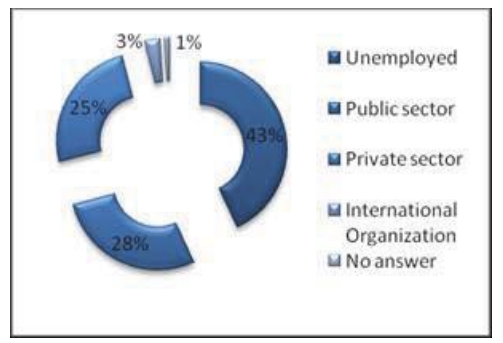

Figure 4: Surveyors by sector of working

In total, 93 students (57\%) of those sample were working, including 46 students (28\%) in public sector and 40 students $(25 \%)$ in the private sector which means that one in four students studying Public Administration is working in the private sector. This causes a change and a deviance in the development of their professional careers.

The indicators used in order measure the academic motivation of the students were: the challenges students take in the moment they choose the branch of study; the control they have in their choice (who chooses for them); the actual pleasure they have from their choice; the importance of their choice in their professional career; and the reason that influences students to choose their particular field. These indicators were chosen based on French, F.B. \& Oakes, W. in this study "The instrument was based on a taxonomy of four types of intrinsic motivators: challenge, control, curiosity, and career outlook" (2003:83). Students' answers will help us to find if the motivation of the students is intrinsic motivation or extrinsic motivation.

Meanwhile, "Intrinsic motivation is the motivation to do something for its own sake, for the sheer enjoyment of a task, the extrinsic motivation is the motivation to do something in order to attain some external goal or meet some externally imposed constraint" (Hennessey, Moran, Altringer, and Amabile, 2015:1). For Rayan and Deci: "Intrinsic motivation is defined as the doing of an activity for its inherent satisfactions rather than for some separable consequence. When intrinsically motivated a person is moved to act for the fun or challenge entailed rather than because of external prods, pressures, or rewards" (2000:56). And "Extrinsic motivation is a construct that pertains whenever an activity is done in order to attain some separable outcome. Extrinsic motivation thus contrasts with intrinsic motivation; which refers to doing an activity simply for the enjoyment of the activity itself, rather than its instrumental value" (Rayan and Deci, 2000:60).

It was found that the student's choices have not got any connection with their motivation. In order to find the kind of students 'motivation, the questionnaires offered some alternatives and students were free to write other alternatives. These alternatives could help the students to know various reasons and to understand which of them it was the reason of their choice.

The auxiliary research question is: Are Albanian students motivated to study Public Administration at university?

In Albania, every person that wants to study Master in public universities (now, with the new Law of High Education and in private universities) needs to complete a ready form, where the candidates have the possibility to choose only 10 study branches. Number 1 represents the higher preference and number 10 is connected with the lowest preference. In 
the academic year of 2015-2016, based on the total number of points, the Ministry of Education decided in which public university students would attended Master Programs. But starting from 2016 - 2017 academic year, public universities will have the right to accept their students by their own choices, without Ministry of Education interference.

Firstly, students were asked how they choose their ten preference branches, in what way, was it an individual decision or affected by others. $63 \%$ of students declared that they choose by themselves; $10 \%$ of students were influenced by others (friends, family and professors); and 27\% didn't give any answer.

Related to the request to rank Public Administration between other branches, $74 \%$ of students gave an answer for ranking number/level while $26 \%$ of students did not declare any ranking number. Figure 5 demonstrates the results.

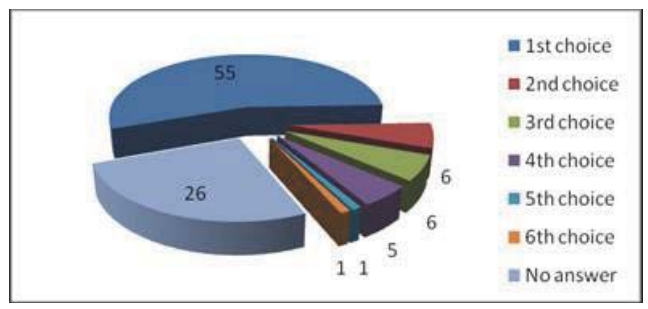

Figure 5: Surveyors by the choice

Most representatives' answers for choosing Public Administration in the first and second place are:

- Desire to work and doing career in public administration institutions.

- Desire to study Public Administration as a new field in Albania.

- Working in public administration is the best alternative in the Albanian labor trade.

- The request by the workplace.

For many students, Public Administration wasn't positioned as the first and second choice, and for this reason they were asked why it was a no-priority choice. As we see in Figure 5, there are $13 \%$ of students that belong to this category. Explanation of this question are reflected in Figure no 6.

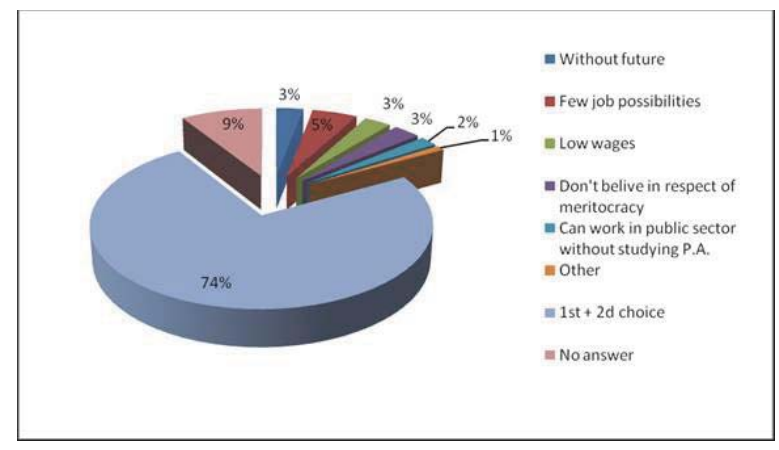

Figure 6: Surveyors by the reasons of non-selection (\%)

$5 \%$ of students thought that public administration institutions offer only "Few job opportunities"; $3 \%$ of students considered jobs in public administration as "Jobs Without future"; $3 \%$ had not chosen it because the public sector has "Low wages" in comparison with private sector. $3 \%$ of them "Don't believe that the recruitment process in civil service is based on meritocracy". 14\% of students don't trust in public administration institutions. Perhaps this mentality was inherited from the autocracy of dictatorship system. Some of them choose: "Study in public administration wasn't a choice, but a suggestion" and some answers were:" Low results in Bachelor, didn't give other choices'.

Figure 7 represents the percentage of every specific reason why Public Administration was chosen as one of alternatives, for students that choose it as the first or second alternative. 


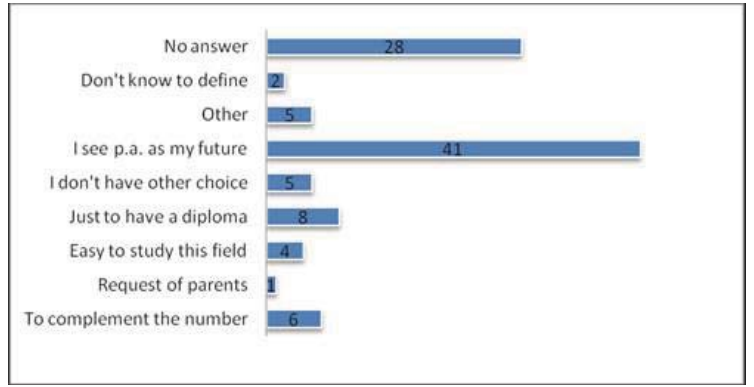

Figure 7: Surveyors by the reasons of the choice (\%)

Among the students, $41 \%$ of them, see the Public Administration as their future; $8 \%$ of students want to study Public Administration: "Just to have a diploma"; $6 \%$ of students want only "To complement the number" on form; $5 \%$ of students have chosen it because they; "Didn't have other choice"; and 4\% of students think that it is "Easy to study this field". 23\% of students or one in four students aren't motivated to study Public Administration, but, just do it.

At the alternative "Other" students gave their opinions and most representatives reasons are:

- Public Administration (P.A.) is an alternative more for the future;

- It has perspective in the future.

- Is very good to have a job in public service.

- To complies the economic and legal knowledge.

Table 5: Correlations

\begin{tabular}{|l|l|c|c|}
\hline \multirow{3}{*}{ Choice of P.A. alternative with a number on form. } & Pearson Correlation & Alternative no. & Reason of choice \\
\cline { 2 - 4 } & Sig. (2-tailed) & 1 & $.211^{* *}$ \\
\cline { 2 - 4 } & $\mathrm{N}$ & 162 & .007 \\
\hline \multirow{2}{*}{ Reason to choice P.A. as a field to study in university. } & Pearson Correlation & $.211^{* *}$ & 1 \\
\cline { 2 - 4 } & Sig. (2-tailed) & .007 & 162 \\
\hline \multirow{2}{*}{$*$ N. Correlation is significant at the 0.01 level (2-tailed). } & $\mathrm{N}$ & 162 & 162 \\
\hline
\end{tabular}

The table above presents the Pearson correlation coefficient, which is the significance value and the sample size where the calculation is based on. The Pearson correlation coefficient $r$ is .211 and this is statistically significant $(p<0.0005)$.

The auxiliary research question is: Which is the expectation of the students for their curriculum at university? For responding it, in the questionnaire are prepared two questions. The first question was about the difficulty level of the curricula. Figure 8 represents answers.

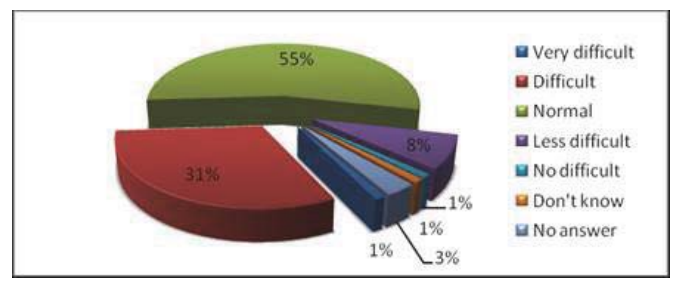

Figure 8: Surveyors for the difficulty of curricula (\%)

One in three students have difficulty to learn the subjects of the curricula. This situation has two explanations:

- Students though that the subject is difficult because they have other engagements and have psychological stress learning it. In fact, some student are employed in the same time they confirmed that they have no time 
to learn.

- Professors approved that the average level of students in Public Administration was moderate. According the Head of Public Administration Department in AMUD, the average mark for Public Administration Students was 7 (seven), while 5 (five) is the minimum passing grade and 10 (ten) is excellent or the maximum one. (Personal communication, 17 September 2015). At the University of Tirana, the situation is the same. One of the Public Administration professors said: "students gained average grades. The quality of students has decreased. The reason is that students end up in this branch because they can't win the right to study in other branches. Students don't choose this field of study because they have no hope for finding jobs in public sector in Albania" (Personal communication, 17 February 2016).

In the other question, students were asked if they want to change something in their curricula. They have three choices; the first was the most important and the third was the less important. In each choice they would select one from the existed alternatives or give another alternative. The results are in Figure 9.

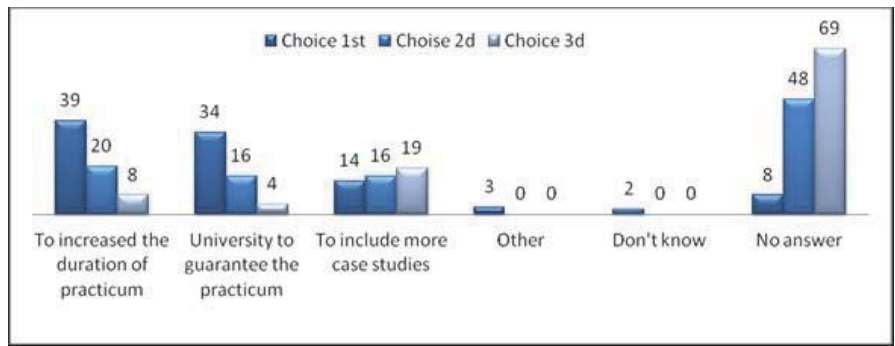

Figure 9: Surveyors for changing in curricula (\%)

In the first choice, $39 \%$ of students want "To increase the duration of practicum"; $34 \%$ of students want that "University to guarantee the practicum"; and 14\% of students want "To include in class more case studies". In the option "Other" the students want:

- More contemporary literature.

- No books translated by using Google Translator.

- The methodology of teaching needs to be changed because students need to learn in logic way and not by memorizing information.

- No repetition subject information from Bachelor level.

- The subject need to be more suitable with the field of public administration.

People thought that in curricula existed many problems they need more professional practicum in public institutions, to help them to put the theory learned into practice.

To answer the auxiliary research question: Which is the level of the collaboration between universities and public administration's institutions in Albania? And for this students' problems the head of departments of two different universities were asked about their opinion. AMUD, the head of public administration department said: "Our Public Administration Department co-operate [in Durrës] with the Working Office, with Port of Durrës, with municipality and with railway for student's practicum" (Personal communication, 17 September 2015). The Head of Management Department the University of Tirana (where is included and Public Administration profile), said that it was an insufficient cooperation with public institutions and it is only for students' practicum (Personal communication, 29 January 2016).

This same situation was confirmed in an interview with two executives from ministries. The General Director of Support Services in Ministry of Transport and Infrastructure (MTI) said: "The cooperation between us and universities is in framework of students' practicum in MTI" (Personal communication, 27 July 2015). The Director of Support Services in Ministry of Energy and Industry declares: "Our institution has an agreement with public universities [in Albania] to complete the practicum for students. During the practicum, the students have a tutor, which is a civil servant with experience, who guides and teaches students at the same time" (Personal communication, 05 October 2015).

The research hypothesis is: there is a relation between the choice of public administration to study in university and the gender of students.

The null hypothesis is: there isn't a relation between the choice of studying public administration in university and student's gender. 
Chi-square Test and Phi and Cramer's Voptions: Chi-Square Tests

\begin{tabular}{|l|c|c|c|}
\hline & Value & Df & Asymp. Sig. (2-sided) \\
\hline Pearson Chi-Square & $13.863^{\mathrm{a}}$ & 8 & .085 \\
Likelihood Ratio & 14.805 & 8 & .063 \\
Linear-by-Linear Association & 1.511 & 1 & .219 \\
N of Valid Cases & 162 & & \\
\hline
\end{tabular}

a. 9 cells (50.0\%) have expected count less than 5 . The minimum expected count is .27 .

Symmetric Measures

\begin{tabular}{|ll|c|c|}
\hline & & Value & Approx. Sig. \\
\hline Nominal by Nominal & Phi & .293 & .085 \\
& Cramer's V & .293 & .085 \\
N of Valid Cases & & 162 & \\
\hline
\end{tabular}

a. Not assuming the null hypothesis.

b. Using the asymptotic standard error assuming the null hypothesis.

As we can see here Chi-square $(2)=13.863, p=.085$ and $p>0.05$, more than the alpha level of significance of 0.05 . The null hypothesis is accepted.

\section{Results and discussions}

$61 \%$ of students have chosen Public Administration as first and second alternative in the form as their challenge; $63 \%$ of students have selected Public Administration as an their own choice, without any influence from others, that means students have control of their choices; and $41 \%$ of students have selected Public Administration as a field to have a career in the future. The majority of students resulted motivated in studying Public Administration at university. It is proved that there is a correlation between the alternative of Public Administration with a number on the form and the reason to choose Public Administration as a field to study in university.

Referring to motivation, the other auxiliary research question was: What kind of the motivation Albanian students have, are they characterized by an intrinsic or extrinsic motivation? Basing on the results, $41 \%$ of students that see themselves as part of Public Administration in their future are clearly in their interne choice and have academic intrinsic motivation. Meanwhile, $29 \%$ of students have chosen Public Administration for simple casual reasons as: Just to have a diploma, to complement the number on the form, with a lower average they didn't have other choices, which are the external motivation for students to study Public Administration. While $28 \%$ of students didn't give an answer.

The perception of the students is that the curricula needs to improve the quality of the practice and of the theory. The students want from the university to guarantee the practicum in public institutions, emphasize the missing collaboration between universities and public administration' institutions. This cooperation is at low levels, only for practicum of students. The usefulness of practicum at students is low because the students ask more time to complete the practicum.

The collaboration between universities and the institutions of public administrations is a necessity for some reasons: firstly it is considered important because it provides students an opportunity to complete a professional practicum. At the same time, they can cooperate between them to common scientific studies which can include; developing common training for civil servants and for people that want to work in the public service; to draft the module and curricula in universities and to draft the curricula for training civil servants.

Students' motivation to study Public Administration is affected negatively by the short time of the practicum, necessity for more case studies in class and by the difficulty they have in learning this subject of the curricula. By increasing the cooperation between universities and public administration' institutions, students can solve many problems and can increase more their motivation.

\section{Conclusion}

This study was conducted to find the indicators that have an impact on the students motivation to study Public Administration and what kind of collaboration exist between the public universities and the public administration' institutions. The majority of students are motivated for studying Public Administration at university. But, $23 \%$ of students 
or one in four students aren't motivated to study Public Administration, but, just do it. Basing it in the results, $41 \%$ of students that want Public Administration as their future are clearly in their interne choice and have academic intrinsic motivation. Meanwhile, $29 \%$ of students have academic extrinsic motivation because have chosen Public Administration for simple casual reasons.

From empirical data analysis it was found that there is a low level of collaboration between universities and public administration institutions in Albania. The cooperation is only for practicum, as a possibility for students to complete them in state institutions, independent institutions or in local institutions.

Students have declared (one in three of them) to have difficulty to study the subjects of the curricula, they want more time for professional practicum in institutions and more case studies in class. The absence of these three elements has a direct impact in their motivation to study public administration at universities. The growth of the cooperation between universities and public institutions would resolve not only those problems, but will influence to increase the students' motivation.

In conclusion we strongly believe that, the strategy for medium and long term investment in Albanian public administration that aims professional and responsible human resources, capable to answer the request of trade should begin with investment at universities, at students as they are the potential future civil servants in public administration. One student formed with appropriate and contemporary knowledge, with necessary practicum in institutions, would be a qualified employer and ready to work in future public sector.

\section{References}

French, F.B. \& Oakes, W. (2003). Measuring academic intrinsic motivation in the first year of college: Reliability and validity evidence for a new instrument. Journal of the First Year Experience, 15, 1, 83-102.

Greenwood, J., Eggins, H. (1995). Teaching public administration a climate of change. Public administration, 73, 1, 143-163.

Greenwood, J., Pyper, R., \& Wilson, D. (2002). The context of British public administration: The discipline of public administration. In New Public Administration in Britain. (3rd ed.) (pp. 2-23). London and New York: Routledge, Taylor and Francis Group.

Hennessey, B., Moran, S., Altringer, B. and Amabile, T. M. (2015). Extrinsic and Intrinsic Motivation. Organizational Behavior, 11, 1-4.

Lynn, L. E. Jr. (1996). The Public Manager as Administrator: Public Administration as Ground. Public Management as Art, Science, and Profession. Unites States of America: Chatham House Publishers, Inc.

Martin, D. W. (1987). Déjà Vu: French Antecedents of American Public Administration. Public Administration Review, 47, 4 (Jul. - Aug.), 297-303.

Ryan, R. M. and Deci, E. (2000). Intrinsic and Extrinsic Motivations: Classic Definitions and New Directions. Contemporary Educational Psychology, 25, 1, 54-67.

Sakli, A. R. (2013). The German and Bluntschli Influence on the Establishment of Public Administration. Journal of Public Administration and Governance, 3, 1, 153-167. [Online] Available: http://www.macrothink.org/journal/index.php/jpag/article/view/3441/2939

Vigoda, E. (2002). The Legacy of Public Administration, Background and review: Transformations of public administration as an academic field. In Vigoda, E. (Ed). Public administration: An interdisciplinary critical analysis (pp. 1-18). New York: Marcel Dekker, Inc.

Woodrow, W. (1887). The Study of Administration. Political Science Quarterly, 2, 2, 197-222. The Academy of Political Science. [Online] Available: http://www.commentary.com/admin_thoughts_1887.pdf 
ISSN 2039-2117 (online)

ISSN 2039-9340 (print)
Mediterranean Journal of Social Sciences MCSER Publishing, Rome-Italy
Vol 7 No 6 November 2016 